\title{
Collective Labour Rights in EU and International Law: Consolidation, Reconciliation
} and Beyond?

\author{
Nicole Busy \\ Professor of Law, University of Strathclyde \\ Rebecca Zahn \\ Lecturer in Law, University of Strathclyde
}

\section{Introduction}

The European Union (EU) legal order has long been at the forefront of the development of social rights as a means of equalising and, in some instances, furthering labour rights.

However, the EU's underlying rationale for the development of social rights has traditionally been one of economic reasoning. At an international level, such rights are articulated as fundamental rights in the European Convention of Human Rights (ECHR), the European Social Charter (ESC) and in Conventions of the International Labour Organisation (ILO). In recent years the EU's relationship with the appropriate international bodies has become increasingly formalised. All EU Member States are members of the ESC ${ }^{1}$ and the ECHR. Both instruments are referred to in the Treaty on the Functioning of the European Union (TFEU) and the Treaty on European Union (TEU) as sources inspiring the social objectives of the EU. The relevant ILO Conventions on freedom of association and collective bargaining have been ratified by all of the EU's member states and thus form part of their constitutional principles. Finally, the Charter of Fundamental Rights (CFR), which, following its enactment by the Treaty of Lisbon forms part of the EU's constitutional order, encompasses the ECHR,

\footnotetext{
${ }^{1}$ A number of states have made reservations to articles 5 and 6 of the ESC which protect the right to organise and the right to bargain collectively. For a full list see http://conventions.coe.int/Treaty/Commun/ListeDeclarations.asp? $\mathrm{NT}=163 \& \mathrm{CM}=\& D F=\& C L=E N G \& V L=1$.
} 
ESC and ILO principles and so can be seen as a linchpin in the consolidation of the EU and international law regimes. At the same time, however, the judicial interpretation given to social rights, particularly collective rights, in the EU and international legal orders is diverging. This gives rise to an interesting conundrum for EU Member States: how should they reconcile their conflicting obligations under the ECHR, ESC and ILO Conventions with those under the EU Treaties?

This chapter begins by considering the relationship between the Member States, the EU and the relevant instruments of international law. The disparate systems under which labour standards have developed impose conflicting obligations on EU Member States in certain respects. The varying interpretations given to the rights to freedom of association and collective action within the EU and international legal orders are used to illustrate such conflict. The chapter assesses the impact that an increasingly formal relationship between EU and international law is likely to have on EU law's supremacy. In conclusion, the authors question whether the CFR, which consolidates the EU and international law regimes, also has the capacity to reconcile the differing labour standards that have evolved.

\section{Relationships of International Law}

The Member States of the European Union are signatories to the ECHR, the ESC and relevant ILO Conventions on freedom of association and collective bargaining (see Table 1).

Table 1 [here] 


\begin{tabular}{|c|c|c|c|c|}
\hline $\begin{array}{l}\text { Adopting Body } \\
\text { Relevant Text }\end{array}$ & European Union & \multicolumn{2}{|c|}{ Council of Europe } & \multirow{2}{*}{$\begin{array}{l}\text { International } \\
\text { Labour } \\
\text { Organisation } \\
\text { Convention } \\
\text { concerning } \\
\text { Freedom of } \\
\text { Association and } \\
\text { Protection of the } \\
\text { Right to Organise } \\
\text { (1950) }\end{array}$} \\
\hline Relevant Text & $\begin{array}{l}\text { Community Social } \\
\text { Charter (CSC) } \\
\text { (1989) } \\
\text { Articles 11-13 } \\
\text { guarantee the right } \\
\text { to freedom of } \\
\text { association, }\end{array}$ & \multirow{3}{*}{$\begin{array}{l}\text { European } \\
\text { Convention } \\
\text { on Human } \\
\text { Rights } \\
\text { (ECHR) } \\
\text { (1953) } \\
\text { Article } 11 \\
\text { protects the } \\
\text { right to } \\
\text { freedom of } \\
\text { association }\end{array}$} & \multirow{3}{*}{$\begin{array}{l}\text { European } \\
\text { Social } \\
\text { Charter } \\
\text { (ESC) } \\
\text { (1965; } \\
\text { revised } \\
\text { 1996) } \\
\text { Article } 5 \\
\text { guarantees } \\
\text { a right to } \\
\text { organise. } \\
\text { Article } 6 \\
\text { protects the } \\
\text { right to } \\
\text { bargain } \\
\text { collectively }\end{array}$} & \\
\hline & $\begin{array}{l}\text { collective } \\
\text { bargaining, and the } \\
\text { right to strike. }\end{array}$ & & & \multirow{2}{*}{$\begin{array}{l}\text { Convention } \\
\text { concerning the } \\
\text { Application of the } \\
\text { Principles of the } \\
\text { Right to Organise } \\
\text { and to Bargain } \\
\text { Collectively } \\
\text { (1951) }\end{array}$} \\
\hline & $\begin{array}{l}\text { Charter of } \\
\text { Fundamental } \\
\text { Rights (CFR) } \\
\text { (2009) } \\
\text { Article } 12 \\
\text { guarantees freedom } \\
\text { of association. } \\
\text { Article } 28 \text { provides } \\
\text { a right of collective } \\
\text { bargaining and } \\
\text { action }\end{array}$ & & & \\
\hline Monitoring Organ & $\begin{array}{l}\text { Court of Justice of } \\
\text { the European } \\
\text { Union (CJEU) }\end{array}$ & $\begin{array}{l}\text { European } \\
\text { Court of } \\
\text { Human } \\
\text { Rights } \\
\text { (ECtHR) }\end{array}$ & $\begin{array}{l}\text { European } \\
\text { Committee } \\
\text { on Social } \\
\text { Rights } \\
\text { (ECSR) }\end{array}$ & $\begin{array}{l}\text { Committee of } \\
\text { Experts }\end{array}$ \\
\hline Member States & $\begin{array}{l}\text { Austria, Belgium, } \\
\text { Bulgaria, Croatia, } \\
\text { Republic of } \\
\text { Cyprus, Czech } \\
\text { Republic, } \\
\text { Denmark, Estonia, } \\
\text { Finland, France, } \\
\text { Germany, Greece, } \\
\text { Hungary, Ireland, } \\
\text { Italy, Latvia, } \\
\text { Lithuania, } \\
\text { Luxembourg, } \\
\text { Malta, Netherlands, } \\
\text { Poland, Portugal, } \\
\text { Romania, Slovakia, } \\
\text { Slovenia, Spain, } \\
\text { Sweden, and the } \\
\text { UK. }\end{array}$ & $\begin{array}{l}\text { All EU } \\
\text { Member } \\
\text { States }\end{array}$ & $\begin{array}{l}\text { All EU } \\
\text { Member } \\
\text { States apart } \\
\text { from } \\
\text { Greece } \\
\text { have } \\
\text { ratified } \\
\text { articles } 5 \\
\text { and } 6 \text {. } \\
\text { Austria } \\
\text { considers } \\
\text { itself } \\
\text { bound by } \\
\text { article } 5 \\
\text { but not } \\
\text { article } 6 .\end{array}$ & $\begin{array}{l}\text { All EU Member } \\
\text { States }\end{array}$ \\
\hline
\end{tabular}


Member States have thus committed to respect the obligations laid down within these texts.

At the same time, EU Member States are bound by EU law including by decisions of the CJEU under the well-known doctrine of supremacy. ${ }^{2}$ Article 351 TFEU provides that rights and obligations that existed between Member States or between a Member State and a third country prior to the State's EU membership 'shall not be affected by the provisions of the Treaties'. Where such agreements are not compatible with the Treaties, the Member State(s) concerned '....shall take all appropriate steps to eliminate the incompatibilities established. ${ }^{3}$ However, because a number of Member States' ratification of the ECHR, the ESC or the ILO Conventions pre-dates their EU membership, ${ }^{4}$ it is unclear whether Member States should give precedence to EU law in cases where this conflicts with their international obligations. ${ }^{5}$ A further complicating factor is the EU's impending accession to the Council of Europe and the ECHR which became an obligation under the Lisbon Treaty ${ }^{6}$ but which does not include the ESC. At the time of writing, the draft Agreement on the EU's Accession to the ECHR is the subject of some uncertainty having been ruled incompatible with EU law by the CJEU. ${ }^{7}$ This development and its likely impact on the furtherance of labour rights will be considered at the end of this chapter.

\section{Collective Labour Rights within the EU and International Legal Orders}

\footnotetext{
${ }^{2}$ Case 26/62 Van Gend en Loos [1963] CMLR 105 and Case 6/64 Flaminio Costa v ENEL [1964] ECR 585.

${ }^{3}$ Cases C-364-365/95 T. Port GmbH \& Co v Hauptzollamt Hamburg-Jonas (1998) ECR I-1023.

${ }^{4}$ For an overview of the dates of ratification for the ECHR see: http://conventions.coe.int/Treaty/Commun/ListeTableauCourt.asp?MA=3\&CM=16\&CL=ENG; for the ESC see: http://www.coe.int/t/dghl/monitoring/socialcharter/Presentation/Overview_en.asp; for Convention 87 see: http://www.ilo.org/dyn/normlex/en/f?p=1000:11300:0::NO:11300:P11300_INSTRUMENT_ID:312232; and, for Convention 98 see:

http://www.ilo.org/dyn/normlex/en/f?p=1000:11300:0::NO:11300:P11300_INSTRUMENT_ID:312243.

${ }^{5}$ See further M Rocca, 'A clash of kings. The European Committee of Social Rights on the 'Lex Laval' ... and on the EU framework for the posting of workers' 2013 European Journal of Social Law 3, 217-232.

${ }^{6}$ See Article 6(2) TEU, and Protocol 8.

${ }^{7}$ Opinion 2/13 of the Court, 18 December 2014.
} 


\section{The European Convention on Human Rights}

The ECtHR has considered collective labour rights on a number of occasions in cases brought under Article 11 ECHR which guarantees the right to freedom of association. ${ }^{8}$ It has consistently held that 'the right to bargain collectively and to enter into collective agreements does not constitute an inherent element of Article 11'9. Similarly, it has always found restrictions on the right to collective action to be justifiable as being "necessary in a democratic society ${ }^{10}$ thereby giving states a wide margin of appreciation. On a number of occasions, ${ }^{11}$ although it did accept the importance of collective action for trade unions, the Court stopped short of explicitly recognising a right to strike. However, in Demir and Baykara the Court held that 'the right to bargain collectively [...] has, in principle, become one of the essential elements of [...] Article 11 of the Convention' ${ }^{12}$, thus enshrining a fundamental right to collective bargaining in the ECHR. The Court justified its change of approach on the basis that it should 'take account of the perceptible evolution in such matters, in both international law and domestic legal systems. ${ }^{, 13}$

In Enerji Yapi-Yol Sen the ECtHR went even further by recognising that 'strike action, which enables a trade union to make its voice heard, constitutes an important aspect in the protection of trade union members' interests. ${ }^{14}$ Ewing and Hendy argue that not only does this decision 'strongly suggest that the court was accepting that the right to strike, insofar as it is exercised in furtherance of collective bargaining, is equally "essential"" but also that "breach of the right

\footnotetext{
${ }^{8}$ For a detailed overview of the ECtHR's jurisprudence, see F Dorssemont, K Lörcher and I Schömann (eds), The European Convention on Human Rights and the Employment Relation (Hart, 2013).

${ }^{9}$ See National Union of Belgian Police (1979-80) 1 E.H.R.R. 578; Swedish Engine Drivers' Union (1979-80) 1 E.H.R.R. 617; and Schmidt and Dahlström v Sweden (1979-80) 1 E.H.R.R. 632.

${ }^{10}$ Supra n. 9. See also Schettini v Italy, Application no. 29529/95, judgment of 9 November 2000.

${ }^{11}$ Wilson v UK [2002] ECHR 552; ASLEF v UK (2007) 45 EHRR 34; UNISON v UK, judgment of 10 January 2002.

12 Para. 154.

13 Para. 153

14 Para. 24.
} 
to strike alone [in this case] was a breach of Article 11. ${ }^{15}$ Unlike in previous cases, the Court did not accept the justification put forward by the Turkish government finding the restriction to be unnecessary in a democratic society. Although, in the subsequent case of RMT $v$ United Kingdom, ${ }^{16}$ the ECtHR has been accused of backtracking by finding a complete ban on secondary strike action to be justified under Article 11(2) ECHR, ${ }^{17}$ it has nevertheless confirmed that the right to strike is "clearly protected' ${ }^{18}$ by Article 11(1) ECHR thereby firmly entrenching a right to strike within the Convention.

\section{The European Social Charter}

The ESC has the same status as the ECHR and acts as its counterpart in the context of economic and social rights by providing a range of minimum labour standards. ${ }^{19}$ It is cited in the preambles of both the TFEU and TEU as a source of inspiration for the EU's social objectives and is referenced in Article 151 TFEU. The ESC's monitoring system which requires member states to submit annual reports to the European Committee of Social Rights $(\mathrm{ECSR})^{20}$ has resulted in a number of decisions on Article $5^{21}$ which guarantees the 'right to organise' and Article 6 which contains the right to collective bargaining (Article 6(2)) and the right to strike (Article 6(4)). Article 5 has been interpreted broadly by the ECSR as including rights to join/not to join a trade union and the prohibition of discrimination of trade union members. Moreover, trade union independence must be assured and excessive state

\footnotetext{
${ }^{15}$ KD Ewing and J Hendy, 'The Dramatic Implications of Demir and Baykara' (2010) Industrial Law Journal 2 , 14.

${ }^{16}$ (2009) 48 EHRR 54.

${ }^{17}$ A Bogg and KD Ewing, 'The Implications of the RMT case' (2014) Industrial Law Journal 221, 222.

${ }^{18}$ Para 83.

${ }^{19}$ See S Evju, 'The European social Charter', in R Blanpain (ed.), The Council of Europe and the Social Challenges of the XXI Century (Kluwer Law, 2001), 19.

${ }^{20}$ The conclusions of the Committee are published every year and posted on the website of the Council of Europe (http://www.coe.int/t/dghl/monitoring/socialcharter/Conclusions/ConclusionsIndex_en.asp).

${ }^{21}$ On Article 5 see NA Casey, The Right to Organise and Bargain Collectively: Protection within the European Social Charter (Council of Europe, Strasbourg, 1996), 11-45.
} 
interference is prohibited. ${ }^{22}$ The ECSR has interpreted Article 6(2) to mean that employers and workers must 'in accordance with legislation of industrial practice [...] [be] at liberty to conclude collective agreements. ${ }^{, 23}$ Under Article 6(4), the ECSR has criticised states for restricting the bases for a right to strike, limiting the beneficiaries of the right and for imposing restrictive procedural requirements on the right itself. However the case law of the ECSR has generally adopted a broad and consistent interpretation of Article 6, defining collective bargaining as 'Any bargaining between one or more employers and a body of employees aimed at solving a problem of common interest, whatever its nature may be. ${ }^{24}$ Conflicts of interest are also referred to in case law on Article 6(4). In its first Conclusions, the Committee recognised:

$[\mathrm{T}]$ he right to collective action only in cases of conflicts of interests. It follows that it cannot be invoked in cases of conflicts of right. ${ }^{25}$

Divergences in national laws on the right to strike have prevented the ECSR from developing a normative interpretation of the concept of collective action and a definitive analytical framework in respect of Article 6(4). ${ }^{26}$ Thus, although there exists a comprehensive body of case law focusing on the right to strike dating back to the its first Conclusions in 1969, the ECSR has been described as a 'relatively ineffective system of control' 27

\section{The International Labour Organisation}

\footnotetext{
${ }^{22}$ For an overview of the decisions see the ECSR's Case law digest 2008 available at http://www.coe.int/t/dghl/monitoring/socialcharter/Digest/DigestSept2008 en.pdf.

${ }^{23}$ See D Harris, The European Social Charter, (2 ${ }^{\text {nd }}$ edn, Transnational Publishers, 2001$), 101$.

${ }^{24}$ Conclusions IV (1975) 50.

${ }^{25}$ Conclusions I (1969-1970) 38.

${ }^{26}$ Evju supra n. 20, 203 and 200.

${ }^{27}$ S Coppola, 'Social Rights in the European Union: The Possible Added Value of a Binding Charter of Fundamental Rights' in G di Federico (ed), The EU Charter of Fundamental Rights: From Declaration to Binding Instrument (Springer, 2011), 203.
} 
Freedom of association and the right to collective bargaining are enshrined in ILO Convention no. 87, 1948 on the Freedom of Association and Protection of the Right to Organize, and Convention no. 98, 1949 on the Right to Organize and Collective Bargaining, both of which have been ratified by all Member States of the EU. ${ }^{28}$ The voluntary negotiation of collective agreements, which is protected under Article 4, Convention 98, is considered to be 'a fundamental aspect of the principles of freedom of association, ${ }^{29}$. The Convention principles also form part of the ILO Declaration on Fundamental Principles and Rights at Work which obliges all members of the ILO, regardless of ratification of the relevant Conventions, to respect, promote and realise, in good faith, the principles contained in the Declaration. The adoption of the 1998 ILO Declaration can be interpreted as evidence of a trend towards greater protection of collective bargaining in international labour law. ${ }^{30}$ Although the Conventions fall short of explicit recognition of a right to collective action, the ILO's Committee of Experts has recognised such action as an intrinsic corollary of the freedom of association contained in Convention no. 87 since the late $1950 \mathrm{~s}^{31}$ and the ILO's Freedom of Association Committee considers collective action to be a fundamental right ${ }^{32}$ and 'one of the essential means through which workers and their organisations may promote and defend

\footnotetext{
${ }^{28}$ These are the main relevant texts. Other ILO conventions and recommendations refer to the respective rights. See A Odero and H. Guido, ILO Law on Freedom of Association: Standards and Procedures, (ILO, 1995). On Convention No. 87 see L Swepston, 'Human Rights Law and Freedom of Association: Development through ILO Supervision’ (1998) International Labour Review 169.

${ }^{29}$ Committee on Freedom of Association Digest of Decisions 1996, para 844.

${ }^{30}$ P Macklem, 'The Right to Bargain Collectively in International Law: Workers' Right, Human Right, International Right?' in P Alston (ed), Labour Rights as Human Rights (OUP, 2005), 68. For a critique of the ambiguous and broad nature of the Declaration see G Mundlak, 'The Transformative Weakness of Core Labour Rights in Changing Welfare Regimes' in E Benevisti and G Nolte (eds), The Welfare State, Globalization and International Law (Springer, 2004) and K Rittich, 'Core Labor Rights and Labor Market Flexibility: Two Paths Entwined?' in International Bureau of the Permanent Court of Arbitration (eds), Labor Law Beyond Borders: ADR and the Internationalization of Labor Dispute Settlement (Wolters Kluwer, 2003).

${ }^{31}$ ILO, Freedom of Association and Collective Bargaining (International Labour Office, Geneva, International Labour Conference, $81^{\text {st }}$ session, 1994). See T Novitz, International and European Protection of the Right to Strike (OUP, 2003), 192-6.

${ }^{32}$ ILO, Freedom of Association, Digest of Decisions and Principles of the Freedom of Association Committee of the Governing body of the ILO ( $4^{\text {th }}$ edn, International labour office, Geneva, 1996), 101, no 473. See also A Jacobs, 'The Law of Strikes and Lockouts' in R Blanpain and C Engels (eds), Comparative Labour Law and Industrial Relations in Market Economies (Kluwer, 1998).
} 
their economic and social interests. ${ }^{33}$ It is unclear whether, through such development, the ILO Committee can be characterised as follower or leader in its relationship with the ESC. ${ }^{34}$

\section{The European Union}

The EU's competence in the sphere of collective rights, particularly freedom of association, collective bargaining and collective action ${ }^{35}$, is limited and any protection takes place largely through their status as fundamental rights. Prior to the introduction of the CFR, the EU recognised these rights in Articles 11 and 12 of the Community Charter of the Fundamental Social Rights of Workers (Community Social Charter - CSC), alongside Article 13, on the right to strike. ${ }^{36}$ The CSC's provisions are arguably more individualist than their ESC or ECHR counterparts. Thus, Article 11(1) precludes the establishment of trade union monopolies ${ }^{37}$ whereas Article 11(2) contains both a positive and a negative right to join a trade union. In contrast, the text of the ESC and the ECHR omit the latter although it has been included through the ECSR's and ECtHR's jurisprudence. The CSC's usefulness is however limited as it merely represents a commitment by Member States to work towards a common set of social policy and labour law objectives ${ }^{38}$ so that the protection it offers is weak. The accompanying Action Programme placed responsibility for the protection and implementation of rights on the Member States 'in accordance with their national traditions and policies. ${ }^{39}$ Nonetheless, the preamble to the Treaty on European Union confirms the Member States'

\footnotetext{
${ }^{33}$ ILO, supra n. 33, para 475.

${ }^{34}$ Novitz, supra n. 32, 196-7.

${ }^{35}$ Article 153 TFEU expressly excludes EU competence in respect of the right to freedom of association and the right to strike. This does not prevent the Union from using alternative legal bases to propose measures on, for example, the exercise of the right to strike. See the failed Monti II proposal COM(2012) 130 proposed under article 352 TFEU. For an overview of the proposal see Freedland and Prassl, EU Law in the Member States: Viking, Laval and Beyond (Hart, forthcoming).

${ }^{36}$ This is subject to obligations arising under national law and is therefore not an absolute right.

${ }^{37}$ See Young, James and Webster v UK, Eur. Ct. H. R., Series B, No. 39.

${ }^{38}$ This was particularly the case between 1989 and 1997 when the UK's opposition to the Charter prevented it from being integrated into the EC Treaty.

${ }^{39}$ COM (89) 568 final.
} 
'attachment to fundamental social rights as defined in the 1989 Community Charter', and Article 151 TFEU makes reference to the CSC. As such, the CSC can be used by the CJEU as an interpretative guide in its judgments dealing with social and labour rights. ${ }^{40}$ The CSC has also been used by the ECtHR in its case law on the right to freedom of association. ${ }^{41}$

Protection of the rights to freedom of association, collective bargaining and collective action is now guaranteed by Articles 12 and 28 CFR. Although the wording of both Articles specifies that their aim is to provide workers with clearly defined rights, ${ }^{42}$ their effectiveness as individually enforceable rights will depend on the CJEU's interpretation. Historically, the Court has adopted a positive approach in recognising the existence of collective labour rights by deriving their protection from the general principles of EU law. Thus, freedom of association was recognised by the CJEU as early as 1974 in Kortner. ${ }^{43}$ Moreover, the Court found a right to collective action to be an integral part of the right to freedom of association in the same case and confirmed the fundamental nature of these two rights in Maurissen. ${ }^{44}$ However, as both cases dealt with conflicts between EU institutions and their staff, this jurisprudence is limited so that although the Court recognised the inviolability of the rights in its judgments it did not establish them as deserving specific protection within the EU's legal order. This was made explicit in later cases such as Werhof where the CJEU recognised freedom of association as 'one of the fundamental rights which [...] are protected in the

\footnotetext{
${ }^{40}$ See, for example, the Viking and Laval cases where inter alia the Charter was used to justify the existence of a fundamental right to strike.

${ }^{41}$ See Sørensen and Rasmussen v Denmark, judgment of 11 January 2006, applications nos. 52562/99 and $52620 / 99$.

${ }^{42}$ Supra n. 42, 228-9.

${ }^{43}$ Case 175/73 Union Syndicale, Massa and Kortner v Commission [1974] ECR at para 14. See also Case 18/74 Syndicat general du personnel v Commission [1974] ECR 933. The Court transferred the recognition of the right to freedom of association to non-labour situations in subsequent cases. See Case C-260/89 ERT [1991] ECR I2925.

${ }^{44}$ Joined Cases C-193/87 and C-194/87 Maurissen and European Public Service Union v Court of Auditors [1990] ECR I-95 at para 21.
} 
[Union] legal order'45 so it is likely that legislative interference with the right ' ...could be successfully challenged'. ${ }^{46}$

The limited protection of the right to freedom of association afforded by the Court prior to the entry into force of the CFR did not automatically imply a right to collective bargaining.

Indeed, the Advocate General in Albany ${ }^{47}$ expressly denied the existence of such a right under EU law. Following the entry into force of the CFR and in light of the ECtHR's recent case law (discussed above), the CJEU seems to have revised its view, concluding in Commission v Germany $^{48}$ inter alia on the basis of Article 28 CFR that the right to collective bargaining should be considered a fundamental right although its exercise can be restricted not only by reference to national law but also in accordance with EU law. ${ }^{49}$ In Commission v Germany, this meant that the fundamental right had to be balanced against the right to freedom of establishment and the freedom to provide services. The Court has taken a similar approach to the fundamental right to take collective action. Whereas the Advocate General in Albany ${ }^{50}$ recognised such a right as being 'protected by Community law' in so far as 'it is indispensable for the enjoyment of freedom of association ${ }^{, 51}$, the CJEU did not recognise the right to strike as a general principle of EU law until 2007 in the controversial Viking and Laval cases. ${ }^{52}$ As

\footnotetext{
${ }^{45}$ Case C-499/04 Werhof [2006] ECR I-2397 at para 33.

${ }^{46}$ C Barnard, EU Employment Law (4 ${ }^{\text {th }}$ edn, Oxford University Press, 2012), 705.

${ }^{47}$ Case C-67/96 [1999] ECR I-5751 at para. 160: 'It cannot be said that there is sufficient convergence of national legal orders and international legal instruments on the recognition of a specific fundamental right to bargain collectively.'

${ }^{48}$ Case C-271/08 [2010] ECR I-7091. For an analysis see P Syrpis, 'Reconciling Economic Freedoms and Social Rights - The Potential of Commission v Germany (Case C-271/08, Judgment of 15 July 2010)' (2011) Industrial Law Journal 222; C Barnard and S Deakin, 'European Labour Law after Laval' in MA Moreau (ed), Before and After the Crisis (Elgar, 2011).

${ }^{49}$ Para 43.

${ }^{50}$ See para 139 where he makes reference to Kortner.

${ }^{51}$ Para 159.

${ }^{52}$ C-438/05 The International Transport Workers' Federation and The Finnish Seamen's Union v Viking Line ABP and OÜ Viking Line Eesti ECR [2007] I-10779; C-341/05 Laval un Partneri Ltd v Svenska Byggnadsarbetareförbundet, Svenska Byggnadsarbetareförbundets avd. 1, Byggettan, Svenska Elektrikerförbundet [2007] ECR I-11767. See, M Rönnmar (ed), EU Industrial Relations vs National Industrial Relations. Comparative and Interdisciplinary Perspectives (Kluwer, 2008); R Blanpain and AM Swiatkowski (eds), The Laval and Viking Cases: Freedom of Services and Establishment v Industrial Conflict in the European Economic Area and Russia (Kluwer, 2009); R Zahn, 'The Viking and Laval Cases in the Context of European
} 
with the right to collective bargaining, based on Article $28 \mathrm{CFR}$, this must be exercised in accordance with EU law and national law and practices. ${ }^{53}$ In addition, in Viking and Laval the Court introduced a proportionality test which must be satisfied if the exercise of the right to strike is to be lawful under EU law. By such means the CJEU has effectively 'disembowelled' 54 the right ${ }^{55}$ of any effect at EU level. The discovery, through the Court's judgments in Viking and Laval, that the CFR's provisions do give rise to specific social rights, which are nevertheless subordinated to their economic counterparts, is unsurprising given the Charter's careful drafting (see below) ${ }^{56}$ However, Article 28 CFR's explicit articulation of workers' 'entitlement' to take strike action might yet provide a mechanism by which the EU's acquis can be extended providing the possibility of a self-standing right. This possibility is explored further below.

\section{Interpreting Social Rights}

In recent years convergence in the standards provided by the ILO's Conventions, the ESC and the ECHR has occurred, particularly with regard to the right to collective action. For example, the ESC's provisions, largely modelled on the equivalent ILO provisions, have been interpreted in broadly similar terms. Moreover, the scope of the ECHR has been progressively widened to include, within the ambit of Article 11, a right to collective action alongside that to collective bargaining. However, it would be wrong to conclude that this fledgling trend has

\footnotetext{
Enlargement' (2008) Web JCLI; N Busby and R Zahn, 'European Labour Law in Crisis: The Demise of Social Rights?' (2013) Contemporary Issues in Law 173; and, articles by A Dashwood, T Novitz, M Rönmar, S Deakin and S Sciarra, in C Barnard (ed), Cambridge Yearbook of European Legal Studies (Hart, 2007-2008).

${ }^{53}$ Article 28 CFR explicitly restricts workers' entitlement 'in cases of conflicts of interest, to take collective action to defend their interests, including strike action' by stating that such entitlement must accord with EU law. ${ }^{54}$ Ewing and Hendy, supra n. 15, 8, footnote 22.

55 The CJEU in Viking (at para 44), referring to Article 28 CFR, held that the right to take collective action constituted 'a fundamental right which forms an integral part of the general principles of Community law'.

${ }^{56}$ Phil Syrpis and Tonia Novitz, 'Economic and social rights in conflict: Political and judicial approaches to their reconciliation' 33 [2008] 3 ELR, 3, 411.
} 
been the cause of any substantive improvement in the provision of labour rights beyond the merely aspirational as, even when combined, the relevant instruments 'tend to be long on promise and short on delivery. ${ }^{57}$ This is not to diminish the potential of such rights to 'mitigate some of the adverse distributional consequences of globalization' as '[ $t$ ]heir normative significance transcends the fact that they are workers' rights or human rights and extends to the justice of the international legal order itself., ${ }^{58}$ (On this point, see BelleAntoine in this volume). At the EU level, the trend towards enhanced protection of labour rights is evident in theory but not in practice. Although the CJEU's case law has progressively led to an acceptance of collective rights as general principles bolstered by the CFR's 'generous provision' ${ }^{59}$ for such rights, recent rulings by the Court fall far short of bestowing such rights with protected justiciable status. This is evident in the Court's interpretation of the fundamental right to strike in Viking and Laval which has become a source of tension between the EU, the ECHR, the ESC and the ILO. For EU Member States, this clash raises a dilemma over conflicting obligations owed at the EU and international levels.

\section{Conflicts between EU and International Law}

EU's law's incompatibility with the ECHR is encapsulated by the rulings of the CJEU and the ECtHR in Viking ${ }^{60}$, Laval $^{61}$, Demir and Baykara ${ }^{62}$, and Enerji Yapi-Yol Sen ${ }^{63}$ which arguably place the courts at opposite ends of a spectrum. By invoking, inter alia, the ECSR's case law,

\footnotetext{
${ }^{57}$ P Macklem, 'The Right to Bargain Collectively in International Law: Workers' Right, Human Right, International Right?' in P Alston (ed), Labour Rights as Human Rights (OUP, 2005), 82.

58 Macklem, supra n. 58.

${ }^{59}$ See B Ryan, 'The Charter and Collective Labour Law' in T Hervey and J Kenner (eds), Economic and Social Rights under the EU Charter of Fundamental Rights: A legal perspective (Hart, 2003), 67-90.

${ }^{60}$ Case C-438/05 [2007] ECR I-10779.

${ }^{61}$ C-341/05 [2007] ECR I-11767.

62 [2009] 48 E.H.R.R. 54

63 (2009, unreported).
} 
the ECtHR's strong support for the rights to collective bargaining and collective action make it difficult to see how it can be reconciled with the CJEU's weakening of the level of protection afforded to such rights in an EU context. However, the EU's impending accession to the Council of Europe and the need for legal certainty make reconciliation unavoidable. ${ }^{64}$ The ECtHR's recent decision in RMT v United Kingdom ${ }^{65}$ can be considered either as a move towards the middle-ground in this respect or a further widening of the chasm that is opening up between the two Courts. In RMT, the ECtHR was asked to consider whether secondary action - which was explicitly rejected as a right deserving protection by the CJEU in Viking comes within the scope of Article 11(1) ECHR. Invoking a range of international instruments ${ }^{66}$ the ECtHR expanded Article 11(1)'s scope by recognising secondary action as part of trade union freedom, on the basis that:

The Convention cannot be interpreted in a vacuum but must be interpreted in harmony with ... any relevant rules of international law applicable in relations between the parties, and in particular the rules concerning the international protection of human rights. ${ }^{67}$

It thus seems clear that, rather than confining itself to an industrial relations conception of the right to strike, the ECtHR is instead following the ILO's example by embracing a human rights conception of collective labour rights. ${ }^{68}$ The ECtHR's judgment nevertheless granted the UK a wide margin of appreciation by finding the state's outright prohibition of secondary

\footnotetext{
${ }^{64}$ See N Busby and R Zahn, 'The EU and the ECHR: Collective and Non-discrimination Labour Rights at a Crossroad?' [2014] 30 IJCLLIR 2, 153.

${ }^{65}$ Application no. 31045/10, judgment of 8 April 2014. See K Istrefi, 'R.M.T. v. The UK: Expanding Article 11 of the ECHR Through Systemic Integration', EJIL Talk!, 12 May 2014 available at $<$ http://www.ejiltalk.org/r-mt-v-the-uk-expanding-article-11-of-the-echr-through-systemic-integration/> accessed 8 June 2015; A Bogg and KD Ewing, 'The Implications of the RMT Case' (2014) Industrial Law Journal 221; John Hendy QC and Michael Ford QC, 'RMT v United Kingdom: Sympathy Strikes and the European Court of Human Rights' (OxHRH Blog, 10 April 2014) available at <http://ohrh.law.ox.ac.uk/?p=5214> accessed 8 June 2015.

${ }^{66}$ Specifically Article 31(3)(c) Vienna Convention on the Law of Treaties, ILO Convention No. 87 and the ESC.

${ }^{67}$ Para 76.

${ }^{68}$ Ewing and Hendy, supra n. 15, 14-16.
} 
strike action to be legitimate and justified, provoking the suggestion that 'the judgment represents nothing short of an appeasement by the ECtHR of the UK government's threats to withdraw from the European Convention. ${ }^{69}$ Although the ECtHR stopped short of granting trade unions greater rights than those recognised by the CJEU, the judgment in $R M T$ does little to reconcile the differing attitudes of the two legal systems regarding the recognition of collective labour rights.

EU law's incompatibility with the Council of Europe's stance on labour rights is not confined to the ECHR but is also evident in its relationship with the ESC. Following the CJEU's judgment in Laval, two Swedish trade union confederations - LO and TCO - submitted a complaint to the ECSR. ${ }^{70}$ In its decision of 20 November 2013 which has been described as 'a direct challenge to the authority of the Court of Justice', ${ }^{71}$ the ECSR unanimously declared the complaint admissible and found that the Swedish legislative amendments resulting from Laval (Lex Laval) violated the rights to collective bargaining and collective action in Article 6 ESC. With regard to the CJEU's judgment, the ECSR emphasised that the EU's free movement provisions, ...cannot be treated, from the point of view of the system of values, principles and fundamental rights embodied in the Charter, as having a greater a priori value than core labour rights, including the right to make use of collective action to demand further and better protection of the economic and social rights and interests of workers. $^{72}$

\footnotetext{
${ }^{69}$ John Hendy QC and Michael Ford QC, supra n. 66. See also N Bratza, 'Living Instrument or Dead Letter - the Future of the European Convention on Human rights' (2014) EHRLR 116.

${ }^{70}$ See Complaint No. 85/2012 Swedish Trade Union Confederation (LO) and Swedish Confederation of Professional Employees (TCO) v Sweden, 12 July 2012.

${ }^{71}$ C Barnard, 'More Posting' (2014) Industrial Law Journal 194, 207.

${ }^{72}$ ECSR, Decision on Admissibility and the Merits Complaint No. 85/2012 Swedish Trade Union Confederation (LO) and Swedish Confederation of Professional Employees (TCO) v Sweden, 3 July 2013 at para 122.
} 
The ECSR concluded that,

$[\mathrm{N}]$ either the current status of social rights in the EU legal order nor the substance of EU legislation and the process by which it is generated would justify a general presumption of conformity of legal acts and rules of the EU with the ESC. ${ }^{73}$

Despite this development, the CJEU's decision in Commission v Germany seems to confirm that it is set on a course of balancing collective labour rights with economic freedoms. As such, it is difficult to envisage how the conflict between the ECSR and the CJEU can be resolved. According to Barnard,

The ECSR's position seems to foreclose any possibility of a dialogue: it is a one-way megaphone communication. Here Realpolitik must step in. If the EU does not respond to the ECSR, the ECSR has few tools at its disposal to force the [CJEU] into compliance. $^{74}$

The clash between the ILO and the EU has become obvious in the wake of a joint complaint regarding the Laval judgment, similar to that to the ECSR, submitted by LO and TCO to the ILO's Committee of Experts (CEACR) in $2010 .{ }^{75}$ Once again, the basis of the complaint was the Swedish legislative changes resulting from the CJEU's judgment which, the according to the trade unions, violated the ILO's conventions on freedom of association and collective bargaining, including the right to strike, and Sweden's ratification of them. Furthermore, the judgment interfered with the unions'

\footnotetext{
73 Para 74.

${ }^{74}$ Barnard, supra n. 72, 210.

${ }^{75}$ Comments by LO and TCO to the ILO's Committee of Experts (CEACR) on Sweden's application of C. 87 and 98 submitted on 31 August 2010.
} 
freedom to decide themselves on which matters they want to regulate in collective agreements and on which legitimate methods [are] to be used in their effort to promote and defend the interest of their members. ${ }^{76}$

In its 2013 General Report on the Application of Conventions and Recommendations, the ILO Committee of Experts agreed with this view expressing deep concern at the consequences of the decision, finding that 'imposing sanctions on unions for leading a legitimate strike is a grave violation of the principles of freedom of association. ${ }^{77}$

As the foregoing examples show, the interrelationship between EU law and international law in the context of collective labour rights has the potential to be contentious and conflictual. For EU Member States, this gives rise to uncertainty due to the differing obligations under the various regimes. Of interest in this context is the potential offered by the CFR which was bestowed with constitutional status under the Lisbon Treaty. As outlined above, the Charter was intended to provide a means of bringing together the ECHR ${ }^{78}$ and ILO principles with the constitutional traditions of the Member States, the jurisprudence of the ECSR and the case law of the CJEU and of the ECtHR. Although the CFR is not intended to be the source of any new provisions but rather to provide a means of making existing rights 'more visible', its status as a catalogue of the full range of rights available to EU citizens imbued with full constitutional force has made it the focus of attention for labour lawyers. ${ }^{79}$ However, whether the Charter's consolidation of the various instruments will lead to a greater reconciliation of

\footnotetext{
${ }^{76}$ Comments by LO and TCO to the ILO's Committee of Experts (CEACR) on Sweden's application of C. 87 and 98 submitted on 31 August 2010, para 3.

${ }^{77}$ ILO, Report of the committee of Experts on the Application of conventions and Recommendations (Report III (Part 1A)) < http://www.ilo.org/wcmsp5/groups/public/---ed_norm/--relconf/documents/meetingdocument/wcms 205472.pdf $>$, 178, accessed 8 June 2015.

${ }^{78}$ Article 52(3) CFR. See also Article 6(2) and (3) TEU.

${ }^{79}$ See some of the contributions in T Hervey and J Kenner (eds) Economic and Social Rights under the EU Charter of Fundamental Rights (Hart Publishing, 2003) and in S Peers, T Hervey, J Kenner and A Ward, The EU Charter of Fundamental Rights (Hart Publishing, 2014); see also S Fredman, 'Transformation or Dilution: Fundamental Right in the EU Social Space' [2006] 12 ELJ 1, 41, 55.
} 
the varying labour standards which apply across different international regimes remains to be seen. We are still at an early stage in the EU's post-Lisbon constitutional arrangements but it is, nevertheless, possible to make some (cautious) predictions regarding the likely effect of those arrangements on labour standards within the EU and international legal orders. In the next section, the CFR's potential impact will be specifically considered in light of its promise as a linchpin capable of consolidating and reconciling the various provisions of international law with their EU counterparts in the context of freedom of association and collective bargaining.

\section{The Charter of Fundamental Rights: Consolidation or Reconciliation?}

Although the full range of international instruments outlined above is of obvious relevance to the issues under review, it is EU law's relationship with the ECHR that has drawn the most attention in this respect. This is perhaps unsurprising given the differences in scope and enforcement relating to the various instruments. As outlined above, the ILO's standards are broadly analogous with the ESC's provisions and, although both have been the subject of broad interpretation, it is the ECHR that has been at the forefront of the expansion of the rights to collective bargaining and to take strike action. In relation to enforcement, although the EU's apparent non-compliance with international standards in the light of the CJEU's judgment in Laval has been the cause of complaints to both the ILO and ECSR, the lack of effective sanctions in respect of both brings to mind Hepple's notion of social rights as 'paper tigers, fierce in appearance but missing in tooth and claw. ${ }^{80}$

\footnotetext{
${ }^{80}$ Bob Hepple (ed), Social and Labour Rights in a Global Perspective (Cambridge University Press, 2002$), 238$.
} 
The lack of effective enforcement has long been the weak link in the ILO's efforts to improve labour standards. Despite its close relationship with the EHRC, the ESC's enforcement regime is very different from its Council of Europe stable-mate: the ECHR allows for individual complaints to the ECtHR whereas the ESC depends on the ECSR's administrative supervision. Whilst the ESC's policy-oriented approach facilitates a broader perspective to be taken than is possible through incremental case law development, the lack of legal force means that compliance is reliant on individual states' willingness to respect the recommendations of the ECSR. The enforcement route offered by the ECtHR is of undoubted appeal to those concerned with the realisation and, where possible, extension of labour rights. Furthermore, the operation of the Court and that of its EU counterpart, the CJEU, against the backdrop of the EU's new constitutional settlement gives rise to some interesting interplay which has the potential to shape the future application and development of the whole range of international instruments. In this respect the CFR acts as a linchpin by bringing the various provisions of international and EU law together. However, alongside its consolidation of the various regimes, is the CFR capable of providing the necessary reconciliation of the divergent standards outlined in this chapter?

The relationship between the EU and the ECHR is still to be formalised. The Lisbon Treaty introduced the necessary constitutional amendments and placed an obligation on the EU to accede to the Convention. ${ }^{81}$ However, the accession process is ongoing: the Draft Agreement, which will allow the EU to become a contracting party to the ECHR, was concluded on 5 April 2013 but has been held by the CJEU to be incompatible with EU law on a number of grounds $^{82}$ sending the negotiators back to the drawing board. Notwithstanding the lack of any formal relationship, the Convention's provisions have long been given expression within the

\footnotetext{
${ }^{81}$ Article 6(2) TEU.

${ }^{82}$ Opinion 2/13 of the Court, 18 December 2014, see further below.
} 
EU acquis largely by the CJEU through their incorporation into the general principles of EU law as outlined above. In addition, the CFR has provided an explicit articulation of the full range of rights available to EU citizens including civic, political, social and economic rights. Rather than introducing any new rights, the intention underlying the CFR is to make preexisting rights "more visible. ${ }^{93}$ In the current context, the relevant provisions are Articles 12 CFR 'Freedom of assembly and of association' ${ }^{84}$ and Article 28 CFR 'Right of collective bargaining and action' ${ }^{85}$

The Charter's status is 'equal to that of the Treaties' ${ }^{86}$ and consequently its provisions have assumed a particular prominence. However, the CFR's high level status does not guarantee its unfettered application across all areas of EU activity: its own provisions are intended to restrict its scope substantially - for example, under Article 28 the right of collective bargaining and collective action must be exercised, 'in accordance with Community law and national laws and practices' - and attempts have been made by certain Member States to narrow its application further in relation to specified activities. For example, the UK's unease with the provision of Article 28 led to the addition of specific appended 'Explanations' and an additional Article (52(5)CFR) ${ }^{87}$ intended to prevent those provisions of the CFR deemed to be 'principles' rather than 'rights' from having direct effect.

\footnotetext{
${ }^{83}$ See the Preamble to the CFR, para 4.

${ }^{84}$ Contained in Chapter II Freedoms which provides, 'Everyone has the right to freedom of peaceful assembly and to freedom of association at all levels, in particular in political, trade union and civic matters, which implies the right of everyone to form and to join trade unions for the protection of his or her interests'.

${ }^{85}$ Contained in Chapter IV Solidarity which provides 'Workers and employers, or their respective organisations, have, in accordance with Community law and national laws and practices, the right to negotiate and conclude collective agreements at the appropriate levels and, in cases of conflicts of interest, to take collective action to defend their interests, including strike action'.

${ }^{86}$ Article 6(3) TEU.

${ }^{87}$ Which states that those provisions of the Charter which contain principles 'may be implemented by legislative and executive acts' of the Union and the Member States when implementing Union law. Such provisions 'shall be judicially cognisable only in the interpretation of such acts and in the ruling on their legality'.
} 
The Charter's scope is further restricted by the horizontal provisions of Title VII, Articles 51-

54 that its interpretation must be consistent with the various sources from which the rights were derived, the most prominent being the Treaties and the ECHR. The Charter is addressed 'to the institutions, bodies, offices and agencies of the Union with due regard for the principle of subsidiarity and to the Member States only when they are implementing Union law'. ${ }^{88}$ Article 51(2) CFR specifies that it does not establish 'any new power or task', or 'modify powers and tasks as defined in the Treaties' so that it cannot extend the EU's competence. Koen Lenaerts, ${ }^{89}$ the CJEU's Vice President, has emphasised the continuing relevance of the Court's previous case law with which the interpretation of the Charter's provisions is bound through Article 51 and associated Explanations. ${ }^{90}$ According to Lenaerts, 'only where the explanations relating to the Charter provide no (complete) answer to the questions of interpretation with which the ECJ is confronted may the latter have recourse to other methods of interpretation. ${ }^{91}$

Article 52 sets down the CFR's scope and relevant interpretation of rights and principles and, in so doing, defines the relationship between the Charter and the Treaties, and between the Charter and the ECHR, respectively. Article 52(2) provides that rights recognised by the CFR 'shall be exercised under the conditions and within the limits' defined by the Treaties so that the Charter does not alter the system of rights conferred by the EU's constitutional law. ${ }^{92}$ Article 52(3) provides that any rights which correspond with those guaranteed by the

\footnotetext{
${ }^{88}$ Article 51(1) CFR. Koen Lenaerts, 'Exploring the Limits of the EU Charter of Fundamental Rights' [2012] 8 ECLR 375, 377.

${ }^{89}$ Lenaerts, supra n. 89, 377. See also the CJEU's judgment in Case C-617/10 Akerberg Fransson [2013] 2 CMLR. 46, paras 20 and 21, in which it proclaims, 'The applicability of European Union law entails applicability of the fundamental rights guaranteed by the Charter.'

${ }^{90}$ OJ 2007 C 303/17. The Explanation relating to Article 51 provides, 'As regards the Member States, it follows unambiguously from the case-law of the [ECJ] that the requirement to respect fundamental rights defined in the context of the Union is only binding on the Member States when they act in the scope of [EU] law'.

${ }^{91}$ Lenaerts, supra n. 89, 402. The Explanations are not legally binding but must be 'given due regard by the court of the Union and of the Member States' Article 52(7) CFR.

${ }^{92}$ EU legislative provisions which are deemed to be contrary to the Charter will be struck down - see Case C92/09 and C-93/09 Volker and Schecke [2010] ECR I-11063; Case C-236/09 Test-Achats [2011] ECR I-000.
} 
Convention shall have the same meaning and scope. It is explicitly provided that this 'shall not prevent Union law providing more extensive protection.' The term 'meaning and scope' includes authorised limitations on the rights so that any exceptions or derogations which may be legitimately imposed on the rights set out in the CFR may not exceed those permitted by the ECHR. Furthermore, Article 53 provides that nothing in the CFR shall restrict or adversely affect human rights and fundamental freedoms as recognised by the ECHR.

The overall effect of the horizontal provisions is that the appropriate level of protection under the ECHR acts as a minimum standard when interpreting analogous provisions of the CFR. However, the picture is far from static as the 'meaning and scope' of the Convention's guaranteed rights are, of course, determined not only by the text itself but also by the case law of the ECtHR ${ }^{93}$ which has, over the years, redefined and increased the level of protection provided by the Convention, notwithstanding its recent disappointing judgment in $R M T .^{94}$ Therefore the past and future case law of the ECtHR must be taken into account in interpreting and applying the CFR. Given the distinct development of the CJEU's and ECtHR's case law in the context of collective labour rights, this may well give rise to problems of consistency. ${ }^{95}$ If the ECtHR raises the level of protection or the scope of application of a fundamental right to a higher level than that applicable under EU law, the CJEU will be obliged to reinterpret the CFR so as to provide the same level of protection, thus challenging EU law's supremacy. ${ }^{96}$ This process, coupled with the fact that its scope is broader than the general principles of EU law, provides the Charter with the potential to add value by expanding the reach of EU law and contributing to the discovery of new general

\footnotetext{
${ }^{93}$ For example Airey v Ireland, Ser A, No 32, 2 EHRR 305 and Soering v United Kingdom, Ser A, No 161, 11 EHRR 439.

${ }^{94}$ Discussed supra n. 17.

${ }^{95}$ See Busby and Zahn, supra n. 65.

${ }^{96}$ Lanaerts, supra n. 89, 394.
} 
principles. ${ }^{97}$ In addition, by enhancing the CJEU's ability to draw on a range of provisions in the social field, the CFR provides new possibilities for the interpretation of existing labour rights. ${ }^{98}$

Rather than being threatened by any conflict between the CFR and ECHR, the potentially broad interpretation of Article 28 CFR is more likely to be limited by the lack of uncertainty as to whether the provisions contained within Chapter IV Solidarity are 'rights' or 'principles'. ${ }^{99}$ However, increased formalisation of the relationship between EU and international law has profound consequences for labour standards in this respect. The distinction between 'rights', more commonly provided under supranational and domestic legal systems, and the 'principles' underpinning international standards is dissolving. The prominence given to international provisions within the EU's acquis by the CFR and the EU's impending accession to the ECHR means that such distinctions are likely to become unsustainable so that principles which are enshrined within the international order will have to be given real credence in future judgments of the CJEU, one example being the wide interpretation given by the ECtHR to freedom of association under Article 11 ECHR. This poses a substantial challenge to EU law's supremacy which, although the cause of some consternation within certain Member States in recent years, has nonetheless afforded them direct influence over the application of labour standards. The EU's new constitutional settlement and the prominent status given to the CFR has brought the provisions of

\footnotetext{
${ }^{97}$ Lanaerts, supra n. 89, 386.

${ }^{98}$ Busby and Zahn, supra n. 65.

${ }^{99}$ The CFR does not distinguish between rights and principles. Where rights are clearly articulated, its text contains specific restrictions relating to their exercise. The revised Explanations to the Charter (OJ 2007 C 303) provide examples of 'principles', for example Article 26 on the integration of persons with disabilities, but they also state that some articles may contain elements of rights and principles. See further C Barnard 'The EU Charter of Rights. Happy 10th Birthday', [2011] 24 EUSA Review 5, available:




international law within the EU's labour law framework thereby reducing Member States' influence. ${ }^{100}$

\section{The New EU Legal Order - Beyond Consolidation and Reconciliation?}

Under the EU's pre-Lisbon constitution the ECHR's provisions, although directly accessible through individual applications to the ECtHR, were rarely invoked by those seeking to assert labour rights. Weak enforcement mechanisms coupled with the perception that lofty human rights standards should be reserved for compelling moral claims rather than being invoked by those seeking enhanced protection of labour rights limited the ECtHR's impact on labour law. However, in the post-Lisbon era, the interplay between the EU acquis and international law has the potential to extend labour rights with the CFR acting as linchpin.

The CFR was intended to consolidate the provisions of international law which, through their incorporation into EU law's general principles, had application in the interpretation of preexisting labour rights. By fulfilling its objective of 'making rights visible', the Charter's articulation of such rights provides it with the potential to move beyond consolidation towards reconciliation. Its use in this context would require a double movement between EU and international law which could go beyond reconciliation towards the extension of labour standards. In the first movement, the CFR's apparently narrow construction of labour rights under its horizontal provisions and the 'rights/principles' distinction, would be widened. Despite guarantees to the contrary, this process is inevitable if the Charter is to meet its selfimposed obligation to maintain the minimum standards under the ECHR including its ongoing

\footnotetext{
${ }^{100}$ For an illustration of this point, see Protocol 30 to the Lisbon Treaty on the Application of the Charter of Fundamental Rights of the European Union to Poland and the United Kingdom discussed in C Barnard, 'The 'Opt-Out' for the UK and Poland from the Charter of Fundamental Rights: Triumph of Rhetoric over Reality?' [2008] 11 Schriftenreihe der Österreichischen Gesellschaft für Europaforschung, 257.
} 
interpretation by the ECtHR. This could significantly enhance the CFR's potential giving rise to the second movement by which any expansion of the relevant general principles initiated by the ECtHR's jurisprudence will find its way into EU law through the CJEU's ongoing interpretation of the CFR.

If realised, this process could give the CFR far greater potential as an agent of change than originally envisaged or indeed intended. If effected, this double movement could provide the opportunity for the extension of labour rights within the EU acquis. An obvious candidate for expansion through this process is collective action which, as this chapter has shown, is the subject of a range of competing standards within EU and international law. With the convergence of both systems, this lack of clarity is surely unsustainable both from the perspective of legal certainty and for those Member States who must reconcile competing obligations under EU and international law. It is therefore perhaps only a matter of time before the ECtHR's more progressive interpretation of Article 11 ECHR reappears with a view to prevailing. This would provide the ultimate test of the EU institutions' and/or Member States' ability to prevent its widespread adoption. In finding the Draft Agreement on the EU's accession to the ECHR incompatible with EU law, the CJEU, objected inter alia to the Agreement's disregard for the specific characteristics of EU Law. In particular, it observed that Article 53 ECHR reserves to the Contracting Parties the power to lay down higher standards, whether in their national laws or in international agreements. In its prior interpretation of the ostensibly similar Article 53 CFR, the Court precluded Member State from having standards that undermine the primacy, unity, and effectiveness of EU Law. ${ }^{101}$ In requiring Article 53 ECHR to be coordinated with Article 53 CFR, including its own interpretation, ${ }^{102}$ the Court has recognised the threat to EU law's supremacy posed by

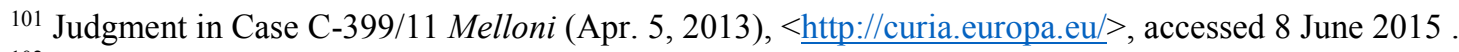

102 See Opinion $2 / 13$ at paras $187-190$.
} 
accession to the ECHR. The EU's accession to the ECHR has been temporarily stalled by the Court's intervention. However, with the conspiring forces of international law and increasingly globalised labour markets, EU law's ability to protect its own supremacy in the longer term remains to be seen. 